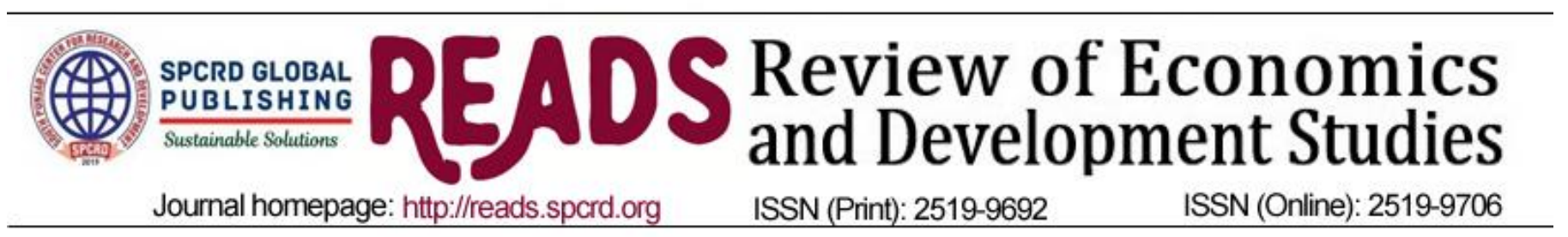

\title{
The Problem of Institutionalization of Political Power in Pakistan: An Appraisal of the Zia Period (1977-1988)
}

\footnotetext{
${ }^{a}$ Kausar Shafiq, ${ }^{\mathrm{b}}$ Abdul Basit Khan, ${ }^{\mathrm{c}}$ Bilal Bin Liaqat, ${ }^{\mathrm{d}}$ Ali Shan Shah

${ }^{a}$ Visiting Faculty Member, Department of Political Science, Bahauddin Zakariya University (BZU), Multan, Pakistan.

Email:kausar9185@gmail.com

${ }^{\mathrm{b}}$ Assistant Professor, Department of Political Science \& IR, Government College University, Faisalabad, Pakistan

${ }^{c}$ Lecturer, Department of Political Science \& IR, Government College University, Faisalabad, Pakistan

${ }^{d}$ Assistant Professor, Department of Political Science \& IR, Government College University, Faisalabad, Pakistan, Email: ali_shan49@yahoo.com
}

\begin{tabular}{l}
\hline ARTICLE DETAILS \\
\hline History: \\
Accepted 17 May 2020 \\
Available Online 15 June 2020
\end{tabular}

\section{Keywords:}

Zia ul Haq, Islamization, Institutionalization of Power, Politics in Pakistan

JEL Classification:

D72, D79, N15

DOI: $10.47067 /$ reads.v6i2.221

\begin{abstract}
Since its establishment in 1947, Pakistan has repeatedly been on starting point or even somewhat beyond the starting point, because of the malfunctioning or non-existence of the state institutions; on such occasions, instead of correcting or rectifying the malfunctioning, the basic infrastructure was altogether demolished while the institutions were abolished thus placing the country on a restart from zero point. Perhaps the Zero point in Islamabad indicates the psychological dimensions of the establishment that they place the country repeatedly at Zero point to start another exercise of trial and error. The military rule by General Ziaul Haq (1977-1988) provides an interesting insight of the above notion since the start of authoritative rather autocratic Islamization during the said regime turned the country back into late $1940 s$ when the proposed Islamization under the Objectives Resolution of 1949 was criticized by the non-Muslim and neutral foreign observers alike. The instant study aims to evaluate whether the state institutions were empowered or strengthened by the Zia regime. It will also evaluate how General Zia's arbitrary use of power affected the performance of government functionaries and public departments.
\end{abstract}

(C) 2020 The authors. Published by SPCRD Global Publishing. This is an open access article under the Creative Commons Attribution-

NonCommercial 4.0

Corresponding author's email address: ali_shan49@yahoo.com

\section{Introduction}

After 1971, the situation was quite conducive rather ideal for evolving a viable civil society and establishing self-sustaining/preserving institutions in the country; because Bhutto was in power at the federal and the provincial level in the Punjab and Sindh, whereas the National Awami party and 


\section{Review of Economics and Development Studies, Vol. 6 (2) 2020, 439-445}

Jamiatul-Ulama-e-Islam coalition was governing the provinces of the North Western Frontier and Baluchistan. Had Bhutto allowed the system to take its shape these three political parties combined together could have performed the processes of Nation Building and State Building in a very adequate and proper manner; because the political parties are formed by the people speaking different languages, professing different religions, belonging to different ethnic and racial stocks, while the membership of a political party ensure that their conflicting interests are articulated and aggregated through minimum consensus, thus making the tasks of Nation and State Building relatively smooth, less complicated and accessible.

Bhutto's autocratic rule during 1971-1977 and his disregard towards democratic norms required the improvisation of the functioning of the institutions instead of their abolition along with suspension of the first ever almost agreed upon constitution. The politicians should have realized that a government by and among themselves, no matter how much undesirable and unfavourable, was certainly better than a government of the non-political element; because there is always a room for negotiations, dialogue, compromise and improvement, which under the army rule cannot be even hoped for. No doubt that some prominent opposition leaders had met a very distasteful treatment at the hands of Bhutto, but that was not the way to correct the situation which they opted for; moreover some of the opposition leaders had even a longer standing in the field of politics and were more seasoned Parliamentarians than he was; hence were expected to have even better appreciation and understanding of the system.

Surprising enough, this Martial Law was unique, because it was demanded and asked for by some of the opposition leaders, for instance Air Marshall Asghar Khan wrote a letter to the Chief of the army staff urging him to take over, while a political leader even that of the status of Wali Khan welcomed Martial Law expressing that he had a sigh of relief because the Martial Law had put the suffocated atmosphere to an end. The opposition leaders for reason best known to them played in the hands of the agencies while Bhutto further mishandling the situation brought the country to the verge of a civil war which provided the armed forces once again the opportunity to demolish the entire institutional infrastructure and impose Martial Law in the country ( Hussain, 1989).

On July 5, 1977, Zia claimed that he had stepped in only to end the chaos which had been created by the political leaders, hence would hold fresh elections and restore the normal political order in the country within 90 days, which were to be held in October instant, but during the election campaign he was informed that Bhutto's party was still the most popular one while the opposition alliance would do a little better than before; hence he put the demand for postponement in their mouth which they readily accepted and demanded that before the elections there must be a process of accountability and those who had misused the power should be taken to task; in the meanwhile a murder case was registered against Bhutto, who was arrested, put on trial and later sentenced to death.

After the elections were postponed, Zia formed a National Government comprising all except Bhutto and his party; particularly Jamaat-I-lslami, being most vocal and instrumental in bringing down Bhutto government, had provided Zia much strength to consolidate and retain his power base.

At that juncture, the higher judiciary played a very crucial role in undermining the constitution, notwithstanding, it owed its existence and oath to the same; the Supreme Court not only validated the army takeover, but without any precedent overstepped to the extent of authorizing the Chief Martial Law administrator to amend the constitution of 1973; nevertheless reserving the power of ratification on case to case basis for itself, which was unprecedented and in contravention of the provisions of the 


\section{Review of Economics and Development Studies, Vol. 6 (2) 2020, 439-445}

constitution because under the same, only the Parliament was empowered to amend the constitution, hence neither the Supreme Court nor the Chief Martial Law administrator had any lawful authority whatsoever to amend the constitution. The relevant portion of the judgment reads:

"the Chief Martial Law Administrator having validly assumed power by means of an extra constitutional step in the interest of the state and for the welfare of the people, is entitled to perform all such acts and promulgate all legislative measures, which have been consistently recognized by judicial authorities as falling within the scope of the law of necessity, namely, all acts of legislative measures which are in accordance with, or could have been made under the 1973 constitution, including the power to amend it”( Pakistan Legal Decisions.1977. p.716).

To start with, Zia accepted the supremacy of the court because before he could deal with the judiciary he had to clear the mess, (Ziring, 1998) consolidate his power until the expiry of the tenure of the President Choudhry Fazal Illahi and the conclusion of the murder trial of Bhutto; hence to avoid the situation that Bhutto must not be pardoned, final judgment of the case was delayed till president Illahi had outlived his tenure and he assumed the office of the President of Pakistan along with the office of the Chief Martial Law administrator. After dealing with Bhutto, he declared that the constitution of l973was held in abeyance, hence no more operative, moreover was nothing more than a few pages which he could tear away any time; he issued the Provisional Constitutional Order which substantially circumscribed the writ jurisdiction of the courts while the judges of the superior courts were required to take fresh oath under the said Order.

Once he had tamed the courts of Law turned to the political leaders who by then had outlived their utility as his allies. He sacked them from their positions, banned all the political parties and placed a ban on all types of political activities. Now he was in his full bloom; hence showing complete disregard for the constitution, the political process, institutions, the political leaders and the political parties.

Zia did not only demolish the state institutions and subjugated the judiciary, he also destroyed the very fabrics of the political parties, which no matter how weak and in-disciplined, are the manifestation of the political will of the people. Instead of evolving an issue-oriented approach to politics, he imposed elections on non-party basis, which was a retrogressive act pushing the people back to the politics, based on the racial, cultural, linguistic and religious bonds. In 1977 the demolition of the institutions was quite uncalled for because the 1973 constitution and the institutions working under the same had everything to provide, hence the performance and functioning of the institutions could be improvised and corrected through the replacement of the individuals. The demolition and abolition of the institutions never provides any remedy rather puts the clock back to start afresh. Individuals are born to differ and they seldom agree; especially in a pluralistic society like Pakistan where the people are divided and cross divided on vertical as well as horizontal levels owning to conflicting interests, culture, language and ethnicity, a minimum consensus to evolve a polity and a civil society is hard to be achieved and once achieved must be maintained and enhanced and not be done away with to restart again from the ashes. Zia did not only demolish the state institutions and subjugated the judiciary, he also destroyed the fabrics of the political parties, which no matter how weak and in-disciplined, are the manifestation of the political will of the people. Political parties are the institutions which evolve minimum consensus among the fragmented people and their conflicting interest.

In 1982-83 an alliance of various political parties launched a Movement for the Restoration of Democracy (MRD), which was much stronger in Sindh than the other provinces because the Sindh his 


\section{Review of Economics and Development Studies, Vol. 6 (2) 2020, 439-445}

felt more frustrated, as they believed that the Sindhi Prime Minister was killed by a Punjabi General. The movement picked such a momentum which was given coverage by local and foreign media; Zia realized that he had lost ground, hence conceded to the demand for restoration of democracy, (Hussain, The Gurdian:1985) because by that time, the U.S had started looking for the revival of somewhat representative government. He realized that to continue in power he had to seek some kind of mandate which might provide legitimacy howsoever weak to his autocratic rule; hence as the first step he planned to get elected as the president no matter with less or no genuine mandate.

In December 1984 Zia through a referendum, widely boycotted by the people at large, declared himself to be elected as President for five years from March 1985 while simultaneously serving as the army chief as a special case. In February 1985 he held elections to the National and Provincial Assemblies on the non-party basis. Meanwhile, when the National Assembly had already been elected, he, claiming his authority to amend the constitution as per judgment in Nusrat Bhutto case, extensively amended the constitution of 1973 under the constitutional Amendment order called the Eight Amendment; which as per his assertion did not require any authentication by the national assembly. Through this amendment, Zia made the constitution of 1973 a Presidential constitution, which originally was framed according to the principles of the Parliamentary form of Government. Zia reserved for himself the power to appoint the Prime Minister, dismiss him when he was pleased to do the same and dissolve the National Assembly. He, in his own discretion, could appoint the chiefs of different forces, the judges of the Superior courts and the Provincial governors who acting under his directions could exercise substantial powers.

In March 1985 Justice Anwarul Haq, the former Chief Justice of Pakistan and the author of the judgment in the Nusrat Bhutto case, released a statement that the Provisional Constitutional Order of 1981[and the Revival of the Constitution Order of 1985] were in contravention of the judgment of the court and had no legal or constitutional validity. He advised the Martial Law authorities to leave the task of amending the constitution to the Parliament. In our analysis, leaving alone the validity of the authority to amend the constitution granted by the supreme court, it was more than absurd that when the national assembly had been elected, Zia unilaterally amended the constitution because logically the authority given by the supreme court was conditioned with the non-existence of the national assembly, hence thereafter, he had no grounds whatsoever to amend the constitution on his own.

As a reaction to the said amendment leaders like Asghar Khan, Ghulam Mustafa Jatoi, Wali Khan, Bizenjo, Nasrullah Khan and others declared that the constitution of 1973 no longer existed, hence a new constitution based on the Lahore Resolution of 1940, was to be framed. Jatoi issued a fourteen point Formula, which if not accepted would lead to a popular movement for the restoration of democracy against the Martial Law. Moreover as a reaction to these amendments, a Sindhi Baluch Pashtoon Front was established in London by Hafeez Pirzada, Mumtaz Bhutto, Attaullah Mengal and others which demanded that the four provinces of Pakistan must form a confederation which in their opinion was the only way Pakistan could be saved from further disintegration. The confederation formula was a substantial departure from the federal constitutional arrangement which was agreed upon by the members of the elected Parliament in 1973.

It can be well said that when the institutions fail to perform their specifically prescribed function or perform extra constitutional functions, the system has to face such problems; moreover if the decisions and policies are not made by the institutions or the decisions and policies made by the institutions are altered by the individuals in arbitrary manner, the agreement and consensus, achieved earlier, on the fundamental issues also ceases to exist and the conflicting interests and differences crop 


\section{Review of Economics and Development Studies, Vol. 6 (2) 2020, 439-445}

up again and fresh efforts to settle already settled issues have to be made. In March 1985 when Zia unilaterally amended the constitution, Pakistan ever since 1971 had to face a constitutional chaos of an unmatchable intensity.

In the light of the above discussion it can be analyzed that the said amendments had damaged the minimum consensus among the political elite over the basic and fundamental constitutional issues and once again had opened a hot debate involving controversial constitutional issues which were settled by the constitution of 1973 notwithstanding the fact that the Bhutto regime had misused power to the resentment of the leaders of the opposition parties who believed that the constitution of the 1973 could be improved to guarantee more Provincial autonomy and less interference by the federal government in the provincial affairs.

After the elections had been held and the 8th amendment inserted, Zia in exercise of the powers under his-self-amended constitution, appointed Muhammad Khan Junejo as the Prime Minister who with his support and blessing obtained the vote of confidence from the assembly. After installing the governments at Islamabad and the Provincial levels, he realized that to legitimize and politicize his army rule he needed a political party; hence, to do the needful, Junejo formed Muslim League in a house which was inherently non-partisan. When challenged by some opposition leaders, the Speaker Syed Fakhar Imam was obliged to admit the motion and ruled that no political party could be formed in a house which was elected on non-party basis; hence those who formed such political party had lost their membership of the National Assembly. Zia, to save the situation, inserted the provision having retrospective effect, which made Fakhar Imam to leave his job and not those who in spite of being elected on non- party basis had formed a political party in the house. Although Junejo was just an average man, nevertheless, to cope with the situation, he exhibited far higher level of ability than expected; his foremost job was to get the Martial Law lifted at the earliest and convince Zia better get his self-styled Eighth amendment ratified by the National Assembly; he told Zia that if he promised a deadline to lift the Martial Law, the house might ratify the Eighth Amendment albeit with some minor modifications.

Taking his suggestions, Zia got his self-styled amendment validated along with all other actions taken by him under Martial Law since July 1977, moreover he also secured a pre-facto approval of his actions which he would take in the period between such approval and the lifting of Martial Law.

Junejo remained the prime minister for about three years, nevertheless during this period substantial powers were exercised by the President and the Governors in the Province and not by the prime minister or National and Provincial assemblies; in spite of lifting the Martial Law Zia continued to hold the office of the Army Chief until March 1990,which was a Presidential system, with a National Assembly having the status of an advisory body and the Cabinet as a team of persons implementing the policies and decisions of the government which meant the President.

It was again a replication of the Vice-regal system in which the institutions were allowed to play a very limited role under a system of controlled and diluted "democracy". Although the1973 constitution, provided a Parliamentary Federal form of government, but the institutions had neither substantial power nor any role to play which they usually performed in such a system. Zia claimed to bridge the gap between the army and political institutions asserting that the army could share the power but could not transfer the same; the supremacy of the armed forces was manifested through the National Security Council, which was overwhelmingly dominated by the chiefs of forces and the Chairman joint chiefs of staff committee, while the Prime Minister and the Chief Ministers were the 


\section{Review of Economics and Development Studies, Vol. 6 (2) 2020, 439-445}

members but without any effective real role to play in the policy- making. Under such an arrangement the institutions like the Parliament and the Provincial assemblies were no more than a showpiece in the power structure. The Daily Telegraph in An editorial "Benazir Homecoming” illustrated: “The problem for General Zia can be stated quite simply. Although, he has brought to Pakistan a greater degree of stability than most people thought likely, General Zia's regime remains what it has always been a rather lackluster dictatorship which is tolerated by many Pakistanis but is wholly unloved. However, after much vacillation and hesitation, General "Zia has recently committed himself to moving towards a form of democracy. The General seems to be hoping that people will be satisfied with sanitized elections from which most of country's genuine politicians will be excluded. That was never very likely and seems even less so now. General Zia will probably have to choose between holding proper elections which might well result in victory for the Pakistan People's Party or the continuation of the unhappy and illegitimate authoritarian rule”( Hussain, The Daily Telegram London,1985, August 22).

During this period, it was reported that a substantial part of the political elite in Baluchistan, Sindh and the North Western Frontier Province had resorted to a violent reaction and people were gathering weapons and ammunitions for armed struggle. Eminent political leaders like Wali Khan, Bizenjo, Khar, Pirzada, Asghar Khan, Bugti and many others expressed the opinion that the Martial Law regime of Zia had widened the gulf between the Punjab and the smaller provinces aggravating the suspicion, distrust and fear of domination among them. These leaders believed that the apprehensions of the smaller provinces about their exploitation and domination by the Punjabi dominated civil and military bureaucracy were no more unfounded and had been confirmed by the successive Martial Law regimes in Pakistan. They believed that in such a situation, as far as the process of Nation Building was concerned, the four provinces of Pakistan were standing somewhat behind the starting point 1947. In the light of these views, it appears that the Zia regime though being successful in retaining power by its sheer force for more than ten years (in1988) had not only utterly failed to accomplish the task of Nation Building rather had reversed it. By 1988 the relationship between the Prime Minister Junejo and President Zia had become uncomfortable because of Junejo's consistent attempts to exercise the authority of the Prime Minister in same manner as the Prime Minister in a Parliamentary form of government usually does, whereas Zia had time and again categorically declared that the army could only share the power with a subordinate and monitored civilian government and had no intention to part with it and transfer it to the civilian government in total. The last straw which broke the camel's back was the secrete sale deed of weapons to Iran by some influential Generals of the Pakistan Army with the blessing of Zia himself. These weapons belonged to the US and were stored in a camp known as Ojri Camp near Rawalpindi to be supplied to the Afghan militants fighting a guerilla war against the Soviet forces in Afghanistan through good offices of the Pakistan government. These weapons were reportedly used by Iran against Iraq and a US team was sent to visit Pakistan and check the said weapons stored in Ojri Camp. Before the needful could be done, on 10 April 1988, the said depot was blown up and the weapons destroyed causing many deaths and casualties in Rawalpindi. Junejo took the matter very seriously and decided to take action against those army generals who were involved in the said sale of arms to Iran. Zia had two options, either to let Junejo proceed against his army generals or in case of saving them, had to sack Junejo from the Prime Minister ship; he exercised the second option sacking Junejo on the charges that he was creating unrest within the ranks of the most sensitive organization i. e the Pakistan Army and was creating a bad will between the Army and the people of Pakistan. He dissolved the National and Provincial assemblies and promised to hold fresh general elections for the same"(Ziring, 1998).

\section{Conclusion}

It can be concluded By that time Zia had outlived his utility for the US government which had 


\section{Review of Economics and Development Studies, Vol. 6 (2) 2020, 439-445}

reportedly lost confidence in him as a care-taker of their strategic interests in the region; moreover, the Soviet forces in Afghanistan had become ineffective to continue their occupation hence rendering Pakistan as redundant to play the role of a Front line State in the region. The US States department saw no further reason and utility to patronize an army general to rule Pakistan, therefore planned to replace him with somewhat representative government; hence Zia along with many other generals was killed in an accident when a Plane carrying him and 29 others including the US Ambassador to Pakistan was blown up in the air as a result of a conspiracy which brought his eleven years rule to a dramatic end.

General Muhammad Aslam Baig succeeded Zia as the Chief of the Army Staff and Ghulam Ishaq Khan, the Chairman of the Senate took over as the Acting President in accordance with the provisions of the constitution of 1973. The dissolution of the assemblies had already been challenged in the court and it was reported that General Aslam Baig pressurized the Judges of the Supreme Court not to revive the assemblies and let the fresh general elections be held on party basis.

The military's decision to stay on the sidelines and support the democratic process was a departure from the policies of Zia-ul-Haq who had strongly favoured the institutionalization of an expanded role of the military. This was a tactical withdrawal based on a realistic assessment of the political situation and did not represent their exit from the political domain or their inability to play a salient role. Before assuming power, Benazir Bhutto had to assure the Army Chief that her government would respect the military's interests and concerns and ensures effective political and economic management (Rizvi, 2013).

To be finally concluded in the words of an eminent historian of Pakistan:

Zia attempted to resolve the Pakistan's long-standing quest for stability by means of Islamization and depoliticization. The result was mounting sectarian violence and increased ethnic conflict, both of which were to assume major proportions in the decade following his death (Talbot, 2014).

\section{References}

Hussain, Fayyaz Ahmad. (1989).The Problem of Federalism and Regional Autonomy in Pakistan. An Unpublished M. Phil Thesis, London: London School of Economics \& Political Science.

Pakistan Legal Decisions. (1977).The Supreme Court of Pakistan.

Ziring, Lawrence. (1998). Pakistan in the Twentieth Century. A Political History. Karachi: Oxford University Press.

Hussain, Fayyaz Ahmad. (1985 March 4) view: The Guardian London.

Hussain, Fayyaz Ahmad. (1985 August 22). view: The Daily Telegram London.

Ziring, Lawrence. (1998). Pakistan in the Twentieth Century. A Political History. Karachi: Oxford University Pres.

Rizvi, Hasan Askari. (2013).The Military and Politics in Pakistan 1947-1997. Lahore: Sang-e-Meel Publications.

Talbot, Ian. (2014). Pakistan: A New History. Karachi: Oxford University Press. 